\title{
Interactive Effects of Impression Management and Organizational Politics on Job Performance
}

\author{
Authors: Suzanne Zivnuska, K. Michele Kacmar, L. \\ A. Witt, Dawn S. Carlson, and Virginia K. Bratton
}

This is the peer reviewed version of the following article: [Zivnuska, Suzanne, K. Michele Kacmar, L. A. Witt, Dawn S. Carlson, and Virginia K. Bratton. "Interactive Effects of Impression Management and Organizational Politics on Job Performance." Journal of Organizational Behavior 25, no. 5 (August 2004): 627-640.], which has been published in final form at http://dx.doi.org/10.1002/job.262. This article may be used for non-commercial purposes in accordance with Wiley Terms and Conditions for Self-Archiving.

Zivnuska, Suzanne, K. Michele Kacmar, L. A. Witt, Dawn S. Carlson, and Virginia K. Bratton. "Interactive Effects of Impression Management and Organizational Politics on Job Performance." Journal of Organizational Behavior 25, no. 5 (August 2004): 627-640. doi:10.1002/job.262.

Made available through Montana State University's ScholarWorks scholarworks. montana.edu 


\title{
Interactive effects of impression management and organizational politics on job performance
}

\author{
SUZANNE ZIVNUSKA ${ }^{1} *$, K. MICHELE KACMAR ${ }^{2}$, L. A. WITT $^{3}$, \\ DAWN S. CARLSON ${ }^{4}$ AND VIRGINIA K. BRATTON ${ }^{2}$ \\ ${ }^{1}$ School of Business, Bond University, Gold Coast, Queensland, Australia \\ ${ }^{2}$ Department of Management, University of Alabama, Tuscaloosa, Alabama, U.S.A. \\ ${ }^{3}$ Department of Management, University of New Orleans, New Orleans, Louisiana, U.S.A. \\ ${ }^{4}$ Department of Management, Baylor University, Waco, Texas, U.S.A.
}

Summary

\begin{abstract}
The purpose of this research was to explore the interactive effect of organizational politics and impression management on supervisor ratings of employee performance. We hypothesized that the negative relationship between organizational politics and supervisor-rated performance is weaker among employees who are high in impression management than among those low in impression management. Data were collected from a matched sample of 112 white-collar employees and their supervisors. Results indicated that the interaction of organizational politics and impression management explained a significant incremental amount of variance in supervisor ratings of employee performance. These findings demonstrated that the extent to which an individual engaged in impression management in a non-political atmosphere may have been a key component to receiving favorable performance ratings. Copyright (C) 2004 John Wiley \& Sons, Ltd.
\end{abstract}

\section{Introduction}

As employees confront scarce resources, increasingly competitive work environments, and an unstable economy, they must find ways to increase their perceived value to the organization. To do this, an individual may engage in political behaviors with the aim of positioning himself or herself as a powerful and crucial person. Organizational politics are defined as '[a]ctions by individuals that are directed toward the goal of furthering their own self-interests without regard for the well being of others within the organization' (Kacmar \& Baron, 1999, p. 4). An employee who perceives that politics are widespread in his or her organization may use impression management tactics to convince others to view him or her as influential or vital. Impression management is a specific type of political behavior intended to persuade an audience to view the actor in a particular way (Schlenker, 1980). Although substantial research exists to support the feasibility of using politics and impression management 
separately to secure desired outcomes (i.e., Ferris et al., 2002; Wayne \& Kacmar, 1991), research has yielded conflicting findings regarding the relationship (Cropanzano, Howes, Grandey, \& Toth, 1997; Harrell-Cook, Ferris, \& Dulebohn, 1999; Randall, Cropanzano, Bormann, \& Birjulin, 1999). Thus, the likelihood of any one individual successfully employing impression management tactics in a political environment remains uncertain.

Although impression management is thought to be one type of political behavior, the relationship that exists between an individual's perception of politics in his or her organization and his or her subsequent attempt to use impression management behaviors has not been investigated, with a few notable exceptions (Ferris, Harrell-Cook, \& Dulebohn, 2000; Harrell-Cook et al., 1999; Valle, 1997; Valle \& Perrewé, 2000). However, evidence suggests that impression management is positively related to employee perceptions of politics (Ferris et al., 2000; Valle, 1997). More specifically, impression management has been found to moderate the relationship between politics and various outcomes, such as job satisfaction, supervisor satisfaction, intent to turnover, and job stress (Harrell-Cook et al., 1999; Valle \& Perrewé, 2000). Recently, Ferris et al. (2002) suggested that theory-based investigation into the relationship between political behaviors (such as impression management), employee perceptions of politics, and their joint influence on organizational outcomes represents a crucial next step in organizational politics research. Adding to this call, several researchers have suggested that further study of the politics-outcome relationship from a motivational perspective, such as expectancy theory, would represent an important contribution to the perceptions of politics literature (Kacmar, Bozeman, Carlson, \& Anthony, 1999; Witt, 1998).

Our purpose was to address that need. We employed expectancy theory (Porter \& Lawler, 1968; Vroom, 1964) to better understand the relationship between impression management and employee perceptions of organizational politics and the joint influence that they exert on performance. Applying expectancy theory to impression management and perceptions of organizational politics allowed us to better explain how individual perceptions may influence an individual's propensity to adjust his or her behavior in pursuit of a high performance evaluation. Accordingly, we investigated the moderating influence of impression management on the relationship between perceptions of politics and supervisor-rated performance.

\section{An Expectancy Theory Perspective on Organizational Politics Perceptions}

Organizational politics research is largely premised on Lewin's (1936) argument that behavior is based on individual perceptions of reality, rather than on an objective measure of what is 'real.' Thus, determining whether an organizational environment is political is a subjective determination that each organizational member must make for himself or herself (Gandz \& Murray, 1980). Even if an employee misinterprets a benign organizational event as political, that 'misperception' of politics constitutes that individual's reality and will guide their subsequent behavior (Ferris, Russ, \& Fandt, 1989; Porter, 1976). Therefore, determining how pervasive politics are in an organization involves studying the extent to which employees perceive organizational politics.

Because political behaviors are those that occur outside of the parameters of formally sanctioned organizational values (Mintzberg, 1985), they are generally perceived by organizational participants as difficult to predict and understand. Although exceptions do exist (e.g., Mintzberg, 1983), it is understandable that past researchers have treated political organizational climates as a primarily negative factor in organizational functioning (Ferris et al., 2002; Liden \& Mitchell, 1988). In fact, perceptions 
of politics have been found to have a negative influence on a number of organizational outcomes, including job anxiety (Cropanzano et al., 1997; Kacmar et al., 1999; Valle \& Perrewé, 2000), job involvement (Cropanzano et al., 1997), job satisfaction (Ferris \& Kacmar, 1992; Nye \& Witt, 1993; Valle \& Perrewé, 2000), intent to turnover (Cropanzano et al., 1997; Kacmar et al., 1999; Maslyn \& Fedor, 1998), actual turnover (Witt, 1999), and employee performance (Kacmar et al., 1999; Witt, 1998).

The negativity associated with high perceptions of politics may be due to the uncertainty inherent in a political environment. If organizational behavior is not governed by a clear set of rules or expectations and behavior is enacted with the sole purpose of personal gain, it is difficult for employees to predict behavior of colleagues, managers, or the executive team. The effect that this uncertainty may have on an individual with high perceptions of politics is best explained from an expectancy theory perspective. The central premise of expectancy theory is that people make behavioral choices that are calculated to allow them to achieve desired outcomes (Porter \& Lawler, 1968; Vroom, 1964). Two valuable rewards that are commonly distributed to employees are money and recognition. Expectancy theory suggests that employees will be more motivated to adjust their behavior to earn a valuable ('high-valence') reward than they will to earn a less valuable reward ('low-valence'). A key component of expectancy theory is the way in which individuals perceive their environment. Individuals are motivated to perform (exert effort) when they perceive that their performance will lead to positive consequences (rewards) that are attainable and valuable (high valence). This effort-performance probability is referred to as expectancy (Porter \& Lawler, 1968). Further, instrumentality is the belief that obtaining this reward will lead to a second outcome which is a larger, more valued reward.

In highly political organizations, rewards are not necessarily related to work performance (Kacmar \& Ferris, 1991), but may instead be tied to relationships, power, and other less objective factors. Because perceptions of politics are related to ambiguous reward structures, in a highly political environment employees may not have confidence that their work behaviors will be recognized, or that valuable rewards will be distributed according to those behaviors (Cropanzano et al., 1997). Thus, high perceptions of politics are likely to be linked to low expectancies because individuals fail to see the full effort-reward relationship. In contrast, in an environment perceived as being low in politics, the link between behavior and rewards is clear and instrumentality is likely to be relatively high, leading employees to be more motivated to adjust their behavior to maximize their chances of earning the desired reward.

Two previous studies (Kacmar et al., 1999; Witt, 1998) have offered empirical support for the direct relationship between politics and performance. Kacmar et al. (1999) measured performance as a selfrated evaluation, and Witt (1998) examined employee performance as rated by supervisors. Consistent with an expectancy theory perspective, both found evidence for a negative relationship between politics and performance.

Therefore, in keeping with theory and prior empirical findings, we hypothesized:

Hypothesis 1: An employee's perceptions of politics are negatively related to supervisor ratings of that employee's performance.

\section{Impression management and performance}

Employees who engage in impression management endeavor to regulate how others perceive them (Rosenfeld, Giacalone, \& Riordan, 1995; Schlenker, 1980). Impression management may take many forms. For example, Jones and Pittman (1982) identified five main categories of impression management behaviors: intimidation, ingratiation, self-promotion, exemplification, and supplication. All five 
of these categories were then collapsed into one with Tedeschi and Melburg's (1984) $2 \times 2$ typology of impression management tactics. In this typology, they differentiated between assertive and defensive tactics and between short-term and long-term tactics. Assertive tactics are used to establish a particular reputation with a specific target audience, whereas defensive tactics are used in response to poor performance. Because the focus of this study is on the way in which employees endeavor to gain favorable performance ratings, we focused on the assertive dimension. Assertive tactics may be self-focused or other focused (Wayne \& Liden, 1995). Self-focused tactics are those that are meant to enhance the view the supervisor has of one's performance. Successful self-focused tactics convince the target that the actor is a model employee: hard working, cooperative, and productive. In contrast, the goal of other-focused impression management tactics is to inspire liking for the actor from the target, and may involve doing favors and giving flattery and praise. Because the goal of self-focused tactics is to directly influence one's performance appraisal, self-focused impression management tactics were our central concern.

From an expectancy theory perspective, an employee is only likely to engage in self-promotional impression management if he or she believes that such behaviors will lead to a favorable reward, such as a positive performance review. If the employee perceives that the supervisor has a very objective measure of performance upon which performance reviews are based, impression management attempts are unlikely. Ultimately, the success of self-focused tactics is determined by the audience's reception of the actor's performed behavior (Bolino, 1999; Crant, 1996; Eastman, 1994; Fandt \& Ferris, 1990; Ferris, Bhawuk, Fedor, \& Judge, 1995). If the supervisor interprets the self-focused impression management tactic as sincere, the likely outcome is an enhanced performance rating. Thus, the employee who believes that he or she is able to convincingly engage in self-promotional impression management behaviors and that those behaviors will improve his or her performance appraisal is likely to try them. Conversely, the employee who does not believe that he or she can convincingly engage in self-promotion or who does not believe his or her supervisor will take such behaviors into account when rating his or her performance is unlikely to attempt them. Thus, theory and empirical findings led us to predict that:

Hypothesis 2: Employee impression management is positively related to supervisor-rated employee performance.

\section{Interactive effects of organizational politics and impression management}

Expectancy theory describes the mechanism by which employees are motivated to manipulate their behaviors in pursuit of a desired reward. We have argued that in an environment perceived as political, uncertainty is high, and that expectancies regarding the performance-reward relationship are corrupted. If employees believe that their environment is political, they are likely to believe that no matter what they do their performance rating will remain constant. Therefore, there is no point in promoting themselves and the good work that they have done, as the effects of such attempts are likely to be washed out. In contrast, if employees perceive their environment as non-political, they have a strong belief that they can successfully alter their behavior in pursuit of attaining a desired reward. These employees are likely to engage in any behavior that might increase the chance of gaining a valued reward, and those who try self-promotion will likely see the benefit of that attempt.

In essence, then, we have argued that in organizational environments characterized by low levels of perceived organizational politics, employees who engage in self-focused impression management behaviors may very well reap the benefit of inflated supervisory ratings. In keeping with this reasoning, we predicted that: 
Hypothesis 3: Impression management moderates the relationship between perceptions of organizational politics and supervisor-rated performance ratings such that when perceptions of organizational politics are low, employees who engage in high levels of impression management are more likely to receive favorable ratings than employees who do not engage in impression management.

Expectancy theory supports the notion that environmental perceptions will alter an individual's propensity to purposefully modify his or her behavior. Using expectancy theory to examine the joint effects of politics and self-focused impression management tactics on supervisor ratings of performance, we attempted to further develop a theoretical understanding of the effect that organizational politics perceptions have on performance outcomes. We joined together two distinct, but related, research streams: politics and impression management.

\title{
Organizational Context
}

\begin{abstract}
The Environment
The organization was in the financial services sector, which has been experiencing significant acquisition activity since the mid 1990s. Financial services jobs had been lost not only in mid-level management but also in frontline customer service and back-office operations areas. Many companies decreased investment in their customer-support infrastructures, requiring fewer workers to meet customer expectations with fewer resources. With the downsizing that followed most of the mergers, the number of workers exceeded the demand for them in the labor market. Because of the reductions in resources and jobs, competition for jobs and promotions became much more intense than had been the case for these workers less than a decade before. As a result, strategic impression management became an increasingly critical asset in managing the careers of many workers.
\end{abstract}

\section{The Organization}

For several years, this organization experienced growth and profit typical for the industry. The business units comprising the sample were organized under a modified matrix structure, yielding multiple constituencies and often multiple bosses for many employees. Despite the matrix-type structure, high levels of organizational politics had not plagued the business units. However, these business units prided themselves on their internal customer service, including care for the employees. Being a customer-centric 'team player' was expected. As a result, some level of nuanced impression management was expected.

\section{The Sample}

The employees served administrative functions in customer service business units. Performance expectations were formally set and tied to business unit performance, which reflected the perceptions and satisfaction of both internal and external customers. Women comprised two-thirds of the sample, while minorities comprised slightly less than a third. The participants ranged in age from 19 to 64 , but about 75 per cent of the sample were less than 40 years of age. Anecdotal evidence suggests very good relations between the managers and employees.

\section{The Timeframe}

The study was conducted in 2002 . 


\section{Method}

\section{Subjects and procedure}

We collected data from a large private-sector financial institution in the Southwest as part of a project conducted for both applied and research purposes. Management sent memoranda to supervisors to request that they ask their employees to participate in the survey process. Participation was entirely voluntary. We were informed anecdotally that only a few employees chose not to participate, and that some were unavailable because of vacation, medical leave, etc. We did not have access to data that would permit assessment of response rate or representativeness of the sample. However, we were aware of no circumstances that would have contributed to any individuals or groups not participating other than absence from work or the apparent rare lack of desire to participate. All responses were kept strictly confidential and individual results were not reported to the organization.

Both employees and supervisors supplied data for this study. A total of 112 white-collar office workers provided data for the independent and control variables, while the respondent's immediate supervisors $(N=14)$ provided the data for the dependent variable. The workers served administrative functions in a customer service organization. Averaging about 33 years in age, they consisted of 37 ( 33 per cent) men and 75 (67 per cent) women; 32 ( 29 per cent) were ethnic minorities and 80 ( 71 per cent) non-minorities. We briefed the relevant results to groups of supervisors, who then presented the results to their employees.

\section{Measures}

\section{Job performance}

We measured overall job performance with six items (e.g., 'He/she maintains positive relations with co-workers'). Supervisors rated their employees on each item using the following scale: (1) 'weak or bottom 10 per cent;' (2) 'fair or next 20 per cent;' (3) 'good or next 40 per cent;' (4) 'very good or next 20 per cent;' or (5) 'best or top 10 per cent.'

\section{Perceptions of organizational politics}

We measured perceptions of organizational politics by the subordinate using the 'Going Along to Get Ahead' subscale of the Perceptions of Organizational Politics Scale (POPS; Kacmar \& Ferris, 1991). This scale consisted of four items measured on a five-point Likert scale. Example items are, 'Employees are encouraged to speak out frankly even when they are critical of well-established ideas' (reverse coded), and 'Telling others what they want to hear is sometimes better than telling the truth.' Higher scores indicate greater perceptions of organizational politics. Kacmar and Carlson (1997) reported additional validity evidence for the full scale and each subscale.

\section{Impression management}

In order to assess impression management from the subordinate, we used the five-item self-focused impression management scale developed by Wayne and Liden (1995). An example item is, 'Work harder when you know the results will be seen by your supervisor.' We measured these items on a five-point Likert scale where higher scores indicated greater impression management.

\section{Control variables}

Participants voluntarily indicated their gender, minority status, and age. We used all three as control variables based on their ability to account for variance in performance outcomes, including evaluations, salary, and promotion (Greenhaus, Parasuraman, \& Wormley, 1990; Judiesch \& Lyness, 1999). 


\section{Results}

Descriptive statistics, correlations, and internal reliability estimates (Cronbach's alpha) among the variables for cases with complete data are presented in Table 1. As shown there, organizational politics was negatively related to supervisor ratings of job performance, offering preliminary support for Hypothesis 1. Hypothesis 2, that impression management and supervisor ratings of job performance would be positively related, also garnered preliminary support.

We present results of the hierarchical moderated regression analyses for centered variables in Table 2. With the control variables entered into the equation, the relationship between perceptions of politics and performance proposed in Hypothesis 1 did not reach significance. Hypothesis 2, that self-focused impression management is positively related to supervisor-rated performance was supported. Finally, as hypothesized, the organizational politics $\times$ impression management cross-product term entered on step three contributed incremental variance over and above the variance contributed by

Table 1. Intercorrelation matrix

\begin{tabular}{|c|c|c|c|c|c|c|c|c|}
\hline Variable & $M$ & SD & 1 & 2 & 3 & 4 & 5 & 6 \\
\hline 1. Age & 33.18 & 12.93 & - & & & & & \\
\hline 2. Gender $(1=$ male, $2=$ female $)$ & 1.67 & 0.47 & 0.06 & - & & & & \\
\hline $\begin{array}{l}\text { 3. Minority status }(1=\text { non-minority; } \\
2=\text { minority })\end{array}$ & ; 1.29 & 0.45 & -0.02 & 0.11 & - & & & \\
\hline 4. Perceptions of politics & 0.00 & 0.92 & -0.06 & 0.04 & $-0.24 * *$ & $(0.70)$ & & \\
\hline $\begin{array}{l}\text { 5. Self-focused Impression } \\
\text { Management }\end{array}$ & -0.00 & 0.71 & 0.04 & 0.12 & $0.22 * *$ & $-0.20^{*}$ & $(0.74)$ & \\
\hline 6. Supervisor-rated performance & 3.53 & 0.74 & -0.02 & -0.02 & -0.07 & $-0.19 *$ & $0.29 * *$ & $(0.86)$ \\
\hline
\end{tabular}

${ }^{*} p<0.05 ;{ }^{* *} p<0.01 . N=112$. Cronbach alphas are reported on the diagonal.

Table 2. Regression analyses of the organizational politics $\times$ impression management interaction on supervisorrated employee performance

\begin{tabular}{|c|c|c|c|c|c|}
\hline Independent variables & $\underset{\beta}{\text { Step } 1:}$ & $\underset{\beta}{\text { Step }} 2$ : & Step 3: & Step 4: & $\Delta R^{2}$ \\
\hline Step 1: Control variables & & & & & 0.01 \\
\hline Gender & -0.02 & 0.00 & -0.03 & -0.03 & \\
\hline Age & -0.00 & -0.00 & 0.00 & 0.00 & \\
\hline Minority status & -0.10 & -0.04 & 0.05 & 0.06 & \\
\hline$F(3,108)=0.19$, adjusted $R^{2}=-0.02$ & & & & & \\
\hline Step 2: Main effect & & & & & 0.03 \\
\hline $\begin{array}{l}\text { Perceptions of politics } \\
F(4,107)=1.06 \text {, adjusted } R^{2}=0.00\end{array}$ & & -0.15 & -0.11 & -0.11 & \\
\hline Step 3: Main effect & & & & & $0.06 * *$ \\
\hline $\begin{array}{l}\text { Self-focused Impression Management } \\
F(5,106)=2.42 * \text {, adjusted } R^{2}=0.06\end{array}$ & & & $0.28 * *$ & $0.24 *$ & \\
\hline Step 4: Cross-product term & & & & & $0.04 *$ \\
\hline $\begin{array}{l}\text { Politics } \times \text { Self-focused Impression } \\
\text { Management }\end{array}$ & & & & $-0.26 *$ & \\
\hline$F(6,105)=2.89^{*}$, adjusted $R^{2}=0.09$ & & & & & \\
\hline Constant & $3.74 * * *$ & $3.60 * * *$ & $3.52 * * *$ & $3.44 * * *$ & \\
\hline
\end{tabular}

${ }^{*} p<0.05 ;{ }^{* *} p<0.01 ;{ }^{* * *} p<0.001$. Standardized regression coefficients for centered variables are presented. $N=112$. 


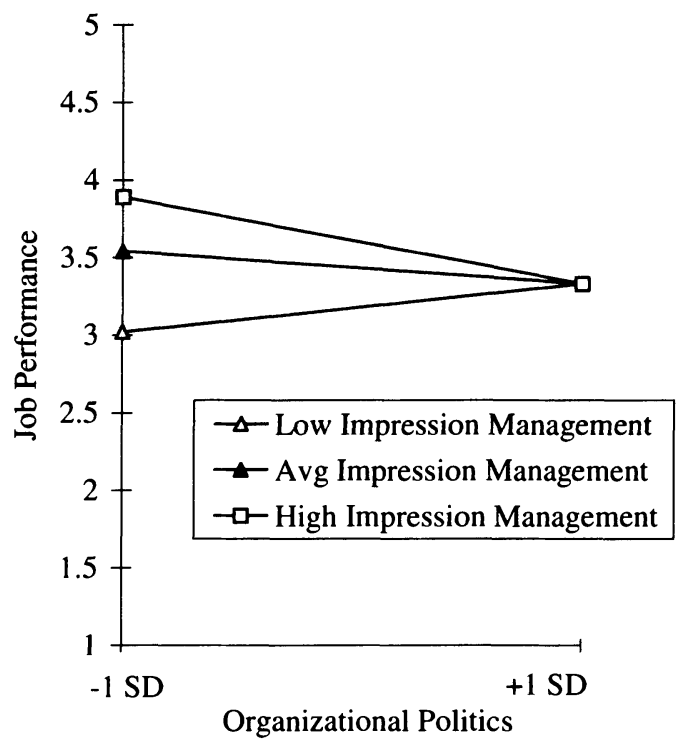

Figure 1. Supervisor-rated job performance regressed on organizational politics: low, average, and high selfpromotion impression management groups. Note: $Y=(0.86-0.26 f) X+(0.93 f-0.28)$. Low score $=1$ standard deviation below the mean; high score $=1$ standard deviation above the mean. Only scores \pm one standard from the mean of organizational politics scores are plotted

the main effects of organizational politics, impression management, and the control variables. The effect size of 0.03 is at the high end of the typical range (i.e., $\Delta R^{2}=0.01$ to 0.03 ) of interaction effects in non-experimental studies (Champoux \& Peters, 1987; Chaplin, 1991).

To identify the form of the interaction, we plotted the equation at its mean as well as at low and high levels of impression management (Stone \& Hollenbeck, 1989). Figure 1 presents the form of the joint relationship of perceived organizational politics and impression management with job performance. Figure 1 indicates a negative perceived organizational politics-job performance relationship among workers employing high levels of impression management; the simple slope was significantly different from zero $(t=2.64, p<0.01$; Aiken \& West, 1991). However, the slopes of the regression lines of the workers at low and mean levels of impression management were not significantly different from zero $(t=0.98$, n.s.; $t=1.45$, n.s., respectively). Moreover, Figure 1 also reveals that impression management was most strongly related to job performance ratings among workers perceiving low levels of organizational politics.

The differences (at one standard deviation above the mean of impression management compared to one standard deviation below the mean of impression management) in predicted values of job performance divided by the standard deviation of job performance (i.e., standardized group differences) were as follows: (a) among individuals with scores at one standard deviation below the mean of organizational politics, impression management yielded a difference of 0.74 standard units of job performance; and (b) for individuals with scores at one standard deviation above the mean of organizational politics, impression management yielded a difference of 0.00 standard units of job performance. Considering Cohen's (1988) categories of effect sizes (i.e., $0.20=$ small, $0.50=$ medium, and $0.80=$ large), the effect of the impression management on job performance was medium and almost large when perceptions of organizational politics were at one standard deviation below the mean. 


\section{Discussion}

Practitioner and scholarly interest in organizational politics and impression management has continued to grow over the years. In part, this high interest may have been due to recognition of the challenges involved in effectively managing one's career in a business climate characterized by scare resources and high competition. Research that helps to illuminate the mechanisms of these constructs stands to make an important contribution to people's ability to attain career success and positively contribute to organizational goals.

Given the amount of attention dedicated to perceptions of organizational politics and impression management, clarifying the nature of their joint effects on performance is important. We answered this challenge by offering expectancy theory (Porter \& Lawler, 1968; Vroom, 1964) as a bridge between these two previously distinct research streams. Our findings support an interaction between politics perceptions and self-focused impression management on performance as hypothesized.

Interestingly, we did not find support for Hypothesis 1, that perceptions of politics would be negatively related to supervisor-rated employee performance. Our lack of significance is inconsistent with our theoretical rational and with past research findings on the politics-performance relationship (e.g., Witt, 1998), and therefore warrants future investigation. Although the lack of significance simply does not allow us to discount the null, it may be consistent with a growing point of view that organizational politics are not always negative, and that they can in fact be functional if they are perceived as giving employees a deeper understanding of organizational processes or obtaining otherwise unavailable resources (Dulebohn \& Ferris, 1999; Ferris et al., 1996). Clearly, these competing views and contradictory results indicate that an exciting opportunity exists for more investigation into the mechanisms that govern the relationship between perceptions of politics and performance.

As predicted by Hypothesis 2, and consistent with past research efforts (Kacmar, Delery, \& Ferris, 1992; Wayne \& Kacmar, 1991), self-focused impression management tactics were positively related to supervisor-rated employee performance. This finding further substantiates the impact that non-work related factors have on performance ratings. However it is important to note that this finding is embedded in the significant higher-order interaction discussed next.

The major contribution of our study was the interaction of organizational politics and impression management attempts on performance ratings. Consistent with our third hypothesis, politics and selffocused impression management interacted in their influence on supervisor ratings of employee performance. This finding indicates that when organizational politics were low, employees who engaged in self-focused impression management tactics were far more likely to receive high performance ratings than employees who did not engage in such tactics. When organizational politics were high, impression management did not affect performance ratings.

We interpreted this finding to mean that when employees perceive their organization as relatively non-political, active impression management may provide employees with a competitive career advantage above and beyond that offered by objective job performance. On the other hand, when employees perceive that politics are pervasive in the organization, there is no incentive to use self-promotion, as performance ratings are constant across all levels of self-focused impression management tactic use. This finding may suggest that managers can identify employees who tend to perceive high levels of organizational politics, and are then more capable at seeing through those employees' attempts at impression management. Conversely, employees who are more circumspect about expressing their perceptions of the organization may be perceived as more sincere by their supervisors. 


\section{Limitations and strengths}

Although this research makes significant contributions to this area of study, there were several limitations. Because this study was based on cross-sectional data, testing the directionality of the hypothesized relationships was not possible. Additionally, incorporating past performance records into this study would have increased the validity of the performance measure. Finally, the restriction of the measurement of perceptions of politics to the 'going along to get ahead' subscale and the focus on exclusively self-promotional impression management behaviors are methodological constraints. Although there was support for the validity of the POPS subscales (Kacmar \& Carlson, 1997), and the self-promotional impression management subscale has been used successfully in past research (Wayne \& Liden, 1995), future researchers should consider broadening their focus on these variables. Such action may allow a more complete picture of the politics-performance relationship to emerge.

This study also had several strengths. First, we used matched-sample data from both subordinates and supervisors, thus reducing the likelihood that common method variance influenced our findings. Second, this study represented an important step in the politics and impression management literature streams. Using expectancy theory to combine these two previously distinct research streams, we were able to explore more fully the importance of both organizational politics and impression management in predicting work outcomes. This broadened perspective enabled us to offer some very practical advice to employees seeking to improve their job performance ratings and may spur further empirical investigations into expectancy theory models of organizational politics and impression management.

\section{Implications for management practice}

The ability to attain strong performance appraisals is critical for employees who want to bolster their job security, attain career success, and ensure job mobility. Our findings suggest that in some situations objective job performance is only one factor in attaining these goals. Employees who became adept at understanding the political frame and behaved accordingly may have had a competitive advantage over those who did not.

These findings provide a strong incentive for practicing managers to identify those employees who take a political view of organizational life. In so doing, they gain an ability to see through superfluous influence attempts and avoid some degree of bias in their performance evaluations. Although impression management is only one source of potential bias among many in the performance appraisal process (halo effects, recency effects, etc.), even small increases in performance appraisal objectivity can have important effects. Conversely, identifying those employees who perceive their organizational environment as relatively non-political may provide some insight into managers as well. These employees because of their 'political naiveté' may tend to come across as quite sincere. Thus, managers may be particularly susceptible to their impression management efforts. Managers who recognize this potential would be better prepared to recognize self-promotional tactics for what they are when faced with an employee who actively engages in them.

Our findings also inspire some advice to employees who perceive their organization as highly political. In such situations, one-upmanship games can produce a spiraling effect that results in hard-tobelieve, self-promotional stories that are met with skepticism by those who hear and judge them. Thus, from a practical perspective, these findings suggest that in highly political environments employees should avoid self-focused impression management attempts. Rather, it may be more appropriate to focus on their objective work productivity and monitor their environment. 


\section{Future research}

Empirical findings that illuminate the role that both organizational politics and impression management behaviors play in successful job performance are important for researchers as well as practitioners. In particular, it appears that further investigation into the positive and negative impacts that perceptions of politics may have on employee performance are warranted. Additionally, we advocate expanding the scope of impression management-performance research to incorporate other-focused influence attempts. We hope that this research will stimulate other scholars in the areas of organizational politics and impression management to continue integrating these fields. By joining the two separate, but related, research streams of politics and impression management, we will be better able to understand the complex nature of the influence each has on employee performance.

Finally, a clear challenge for future research is to expand the scope of organizational politics research. This challenge could be met empirically and theoretically. Empirically, it would be useful to incorporate an independent measure of the extent to which politics exist in an organizational environment. The constraint of measuring organizational politics as a perceptual measure is limiting in terms of the research questions that can be asked and the ability of our data to answer those questions. An independent, broad measure of political activity would add even more interest to this research area.

Theoretically, the dramaturgical approach might help researchers to explain complex political phenomena and impression management behaviors (Goffman, 1959). The dramaturgical interpretation of social interaction suggests that social behavior involves presenting a message to an intended audience in a way that encourages desired outcomes, providing a mechanism by which impression management behaviors can be explained. Under this perspective, social interaction is viewed as a performance that is shaped by both an individual's environment and his or her audience, and its purpose is to lead the audience to form impressions that are consistent with the actor's goals (Goffman, 1959). The theory can also be used to explain political behaviors, as it suggests that an actor may be saddled with the challenge of presenting behavior to his or her audience consistent with prevalent social norms, while simultaneously pursuing personal goals that may contradict these norms (Goffman, 1959).

The dramaturgical approach to social interaction has primarily spurred research in the areas of impression management and leadership. This approach has been especially useful in describing the process of human behavior (Brissett \& Edgely, 1975). For example, Bozeman and Kacmar (1997) used dramaturgy to build a cybernetic model describing impression management processes in organizations. Similarly, Gardner and Avolio (1998) developed a dramaturgical model to describe the charismatic relationship between leaders, followers, their behaviors, and their environment. Although both of these models offer useful theoretical descriptions of human behavior in the realms of impression management and leadership, neither has been tested. In fact, the inherently complicated nature of social interaction may offer one explanation for why dramaturgy has not been employed more frequently in management research. Thus, a potentially rich area of future research would be one that incorporates and empirically tests a dramaturgically derived model of impression management and political behavior.

In conclusion, this research demonstrates the importance of further considering the nature of the relationship that exists between organizational politics and impression management. Our findings have important implications for organizational practitioners who are responsible for providing accurate, fair performance ratings. Additionally, we hope that our results provide organizational scholars with some new insight about the relationship between political perceptions, political behavior, and their joint impact on performance outcomes. 


\section{Author biographies}

Suzanne Zivnuska is an Assistant Professor of Management at Bond University. Her PhD is in Organizational Behavior and Human Resource Management from Florida State University. Her research interests include communication, impression management, and employee performance.

K. Michele (Micki) Kacmar is the Durr-Fillauer Chair of Business Ethics at the University of Alabama. Her PhD is in Human Resource Management from Texas A\&M University. Dr Kacmar's general research interests are in the areas of impression management and organizational politics.

L. A. Witt, formerly a human resources director in the private sector, is an Associate Professor of Management at the University of New Orleans. His work has focused on such topics as organizational politics, social skill, and personnel selection.

Dawn S. Carlson is an Associate Professor of Management at Baylor University. Her PhD is in Organizational Behavior and Human Resource Management from Florida State University. Dr Carlson's general research interests are in the areas of work-family conflict and impression management.

Virginia K. Bratton is a PhD candidate in Organizational Behavior and Human Resource management at Florida State University. Her research focuses on ethical decision making.

\section{References}

Aiken, L. S., \& West, S. G. (1991). Multiple regression: Testing and interpreting interactions. Newbury Park, CA: Sage.

Bolino, M. (1999). Citizenship and impression management: good soldiers or good actors? Academy of Management Review, 1, 82-98.

Bozeman, D. P., \& Kacmar, K. M. (1997). A cybernetic model of impression management processes in organizations. Organizational Behavior and Human Decision Processes, 69, 9-30.

Brissett, D., \& Edgley, C. (1990). The dramaturgical perspective. In D. Brissett, \& C. Edgley (Eds.), Life as theater: A dramaturgical sourcebook (2nd ed., pp. 1-46). New York: Aldine de Gruyter.

Champoux, J. E., \& Peters, W. S. (1987). Form, effect size, and power in moderated regression analysis. Journal of Occupational Psychology, 60, 243-255.

Chaplin, W. F. (1991). The next generation of moderator research in personality psychology. Journal of Personality, 59, 143-178.

Cohen, J. (1988). Statistical power analysis for the behavioral sciences. Hillsdale, NJ: Erlbaum.

Crant, J. M. (1996). Doing more harm than good: when is impression management likely to evoke a negative response? Journal of Applied Social Psychology, 26, 1454-1471.

$\rightarrow$ Cropanzano, R., Howes, J. C., Grandey, A. A., \& Toth, P. (1997). The relationship of organizational politics and support to work behaviors, attitudes, and stress. Journal of Organizational Behavior, 18, 159-180.

Dulebohn, J. H., \& Ferris, G. R. (1999). The role of influence tactics on fairness perceptions of performance evaluations. Academy of Management Journal, 42, 288-303.

Eastman, K. K. (1994). In the eyes of the beholder: an attributional approach to ingratiation and organizational citizenship behavior. Academy of Management Journal, 37, 1379-1392.

Fandt, P. M., \& Ferris, G. R. (1990). The management of information and impressions: when employees behave opportunistically. Organizational Behavior and Human Decision Processes, 45, 140-158.

Ferris, G. R., Adams, G., Kolodinsky, R. W., Hochwarter, W. A., \& Ammeter, A. P. (2002). Perceptions of organizational politics: theory and research directions. In F. Dansereau, \& F. J. Yammarino (Eds.), Research in multi-level issues (Vol. 1, pp. 179-254). Oxford, UK: Elsevier Science/JAI Press.

Ferris, G. R., Bhawuk, D. P. S., Fedor, D. B., \& Judge, T. A. (1995). Organizational politics and citizenship: attributions of intentionality and construct definition. In M. J. Martinko (Ed.), Advances in attribution theory: An organizational perspective (pp. 231-252). Delray Beach, FL: St. Lucie Press. 
Ferris, G. R., Frink, D. D., Galang, M. C., Zhou, J., Kacmar, K. M., \& Howard, J. L. (1996). Perceptions of organizational politics: predictors, stress-related implications, and outcomes. Human Relations, 49, 233-266.

Ferris, G. R., Harrell-Cook, G., \& Dulebohn, J. H. (2000). Organizational politics: the nature of the relationship between politics perceptions and political behavior. In S. B. Bacharach, \& E. J. Lawler (Eds.), Research in the sociology of organizations (Vol. 17, pp. 89-130). Stamford, CT: JAI Press.

Ferris, G. R., \& Kacmar, K. M. (1992). Perceptions of organizational politics. Journal of Management, 18, 93-118.

Ferris, G. R., Russ, G. S., \& Fandt, P. M. (1989). Politics in organizations. In R. A. Giacalone, \& P. Rosenfeld (Eds.), Impression management in the organization (pp. 143-170). Hillsdale, NJ: Erlbaum.

Gandz, J., \& Murray, V. (1980). The experience of workplace politics. Academy of Management Journal, 23, 237-251.

$\rightarrow$ Gardner, W. L., \& Avolio, B. J. (1998). The charismatic relationship: A dramaturgical perspective. Academy of Management Review, 23, 32-59.

Goffman, E. (1959). The presentation of self in everyday life. Garden City, NY: Doubleday.

Greenhaus, J. H., Parasuraman, S., \& Wormley, W. M. (1990). Effects of race on organizational experiences, job performance evaluations, and career outcomes. Academy of Management Journal, 33, 64-86.

$\rightarrow$ Harrell-Cook, G., Ferris, G. R., \& Dulebohn, J. H. (1999). Political behaviors as moderators of the perceptions of organizational politics-work outcomes relationships. Journal of Organizational Behavior, 20, 1093-1105.

Jones, E. E., \& Pittman, T. S. (1982). Toward a general theory of strategic self-presentation. In J. Suls (Ed.), Psychological perspectives on the self (Vol. 1, pp. 231-263). Hillsdale, NJ: Erlbaum.

Judiesch, M. K., \& Lyness, K. S. (1999). Left behind? The impact of leaves of absence on managers' career success. Academy of Management Journal, 42, 641-651.

Kacmar, K. M., \& Baron, R. A. (1999). Organizational politics: the state of the field, links to related processes, and an agenda for future research. In G. R. Ferris (Ed.), Research in personnel and human resources management (Vol. 17, pp. 1-39). Stamford, CT: JAI Press.

Kacmar, K. M., Bozeman, D. P., Carlson, D. S., \& Anthony, W. P. (1999). An examination of the perceptions of organizational politics model: replication and extension. Human Relations, 52, 383-416.

Kacmar, K. M., \& Carlson, D. (1997). Further validation of the Perceptions of Politics Scale (POPS): a multiple sample investigation. Journal of Management, 23, 627-658.

Kacmar, K. M., Delery, J. E., \& Ferris, G. R. (1992). Differential effectiveness of applicant impression management tactics on employment interview decisions. Journal of Applied Social Psychology, 22, 1250-1272.

Kacmar, K. M., \& Ferris, G. R. (1991). Perceptions of Organizational Politics Scale (POPS): development and construct validation. Educational and Psychological Measurement, 51, 193-205.

Lewin, K. (1936). Principles of topological psychology. New York: McGraw-Hill.

$\rightarrow$ Liden, R. C., \& Mitchell, T. R. (1988). Ingratiatory behaviors in organizational settings. Academy of Management Review, 13, 572-587.

Maslyn, J., \& Fedor, D. B. (1998). Perceptions of politics: does measuring different foci matter? Journal of Applied Psychology, 84, 645-653.

Mintzberg, H. (1983). Power in and around organizations. Englewood Cliffs, NJ: Prentice-Hall.

Mintzberg, H. (1985). The organization as political arena. Journal of Management Studies, 22, 133-154.

Nye, L. G., \& Witt, L. A. (1993). Dimensionality and construct validity of the Perceptions of Organizational Politics Scale (POPS). Educational and Psychological Measurement, 53, 821-829.

Porter, L. W. (1976). Organizations as political animals. Presidential address, Division of IndustrialOrganizational Psychology, 84th Annual Convention of the American Psychological Association, Washington, DC; September.

Porter, L. W., \& Lawler, E. E. (1968). Managerial attitudes and performance. Homewood, IL: Richard D. Irwin. $\rightarrow$ Randall, M. L., Cropanzano, R., Bormann, C. A., \& Birjulin, A. (1999). Organizational politics and organizational support as predictors of work attitudes, job performance, and organizational citizenship behavior. Journal of Organizational Behavior, 20, 159-174.

Rosenfeld, P., Giacalone, R. A., \& Riordan, C. A. (1995). Impression management in organizations: Theory, measurement, practice. London: Routledge.

Schlenker, B. (1980). Impression management: The self-concept, socials identity, and interpersonal relations. Monterey, CA: Brooks/Cole.

Stone, E. F., \& Hollenbeck, J. R. (1989). Clarifying some controversial issues surrounding statistical procedures for detecting moderator variables: empirical evidence and related evidence. Journal of Applied Psychology, 74, $3-10$. 
Tedeschi, J. T., \& Melburg, V. (1984). Impression management and influence in the organization. In S. B. Bacharach, \& E. J. Lawler (Eds.), Research in the sociology of organizations (Vol. 3, pp. 31-58). Greenwich, CT: JAI Press.

Valle, M. (1997). Perceptions of organizational politics and subsequent behaviors. Psychological Reports, 81, 945-946.

Valle, M., \& Perrewé, P. L. (2000). Do politics perceptions relate to political behaviors? Human Relations, 53, 359-386.

Vroom, V. H. (1964). Work and motivation. New York: Wiley.

Wayne, S. J., \& Kacmar, K. M. (1991). The effects of impression management on the performance appraisal process. Organizational Behavior and Human Decision Processes, 48, 70-88.

Wayne, S. J., \& Liden, R. C. (1995). Effects of impression management on performance ratings: a longitudinal study. Academy of Management Journal, 38, 233-260.

Witt, L. A. (1998). Enhancing organizational goal congruence: a solution to organizational politics. Journal of Applied Psychology, 83, 666-674.

Witt, L. A. (1999). I am outta here: Organizational politics vs. personality predicting turnover. Presented at the meeting of the Academy of Management, Chicago; August. 